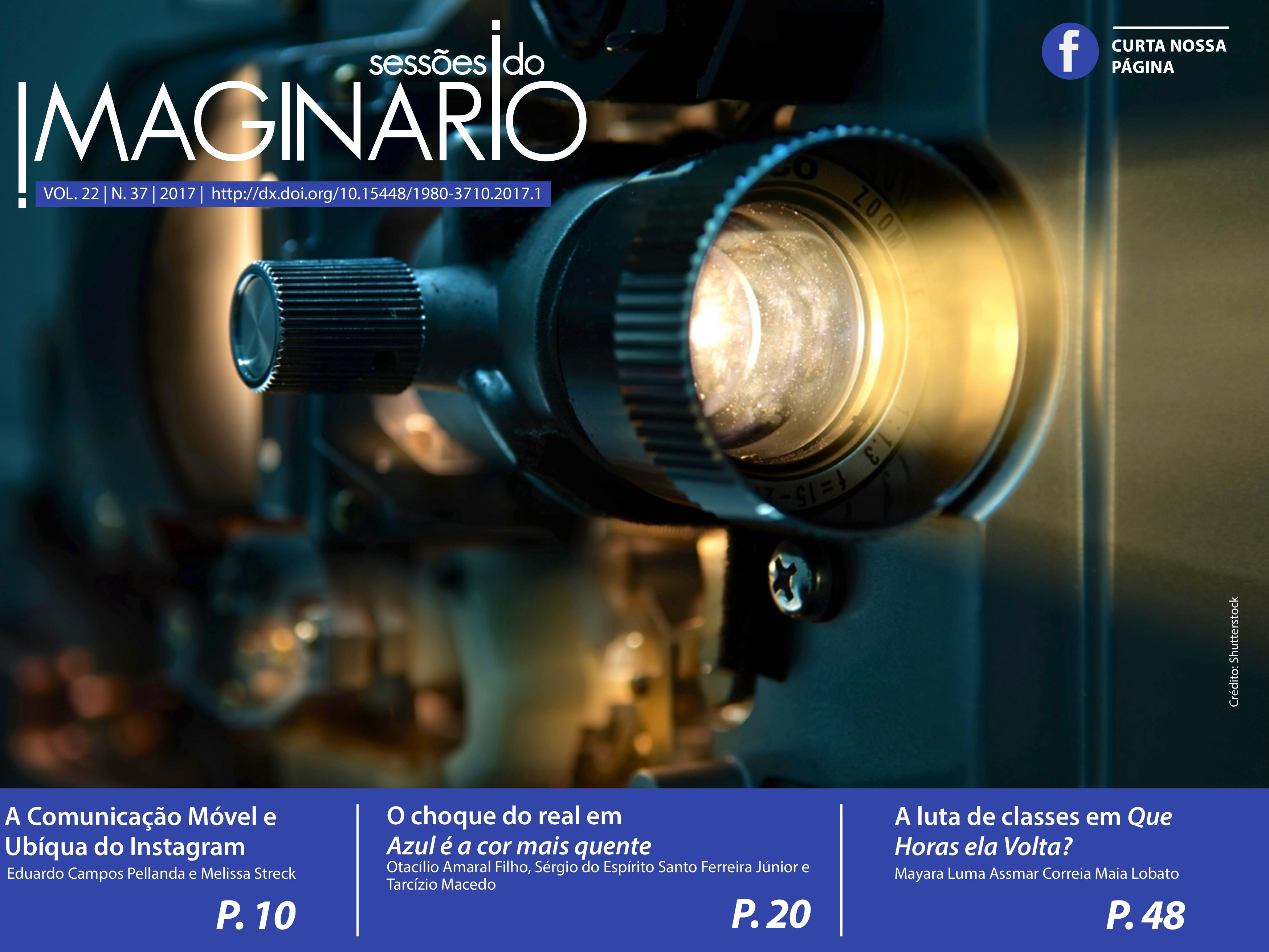




\section{Metodologias de Pesquisa em Telejornalismo ${ }^{1}$}

\section{Research Methodologies in Telejournalism}

\section{Cárlida Emerim²

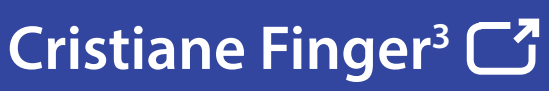 \\ Beatriz Cavenaghi ${ }^{4} \square$}

\section{AUTOR}

CONVIDADO

02 PORTO ALEGRE | v. 22 | n. 37| 2017| pp. 02-09 DOI: http://dx.doi.org /10.15448/1980-3710.2017.1.28073 Sessões do Imaginário

\section{Resumo}

O campo do telejornalismo tem se consolidado como área de pesquisa nos últimos dez anos. Neste período a predominância dos estudos de caso empresta à área uma fase introdutória dos processos teóricos. O presente artigo prevê avançar um pouco nesta perspectiva e apresenta modelos metodológicos que vêm sendo testados por diferentes pesquisadores na proposição de uma teoria do jornalismo, que visa referendar os estudos e pesquisas em telejornalismo no Brasil. Para tanto, apresenta, na primeira parte, os percursos metodológicos mais utilizados nos últimos anos por grupos de estudo e pesquisa de referência e, na segunda parte, explicita duas propostas metodológicas que contemplam a audiência, a recepção e os processos de pesquisa empreendidos.

\section{Palavras-chave}

Telejornalismo; pesquisa; metodologia; análise de audiência; análise de recepção.

\section{Abstract}

Telejournalism's field has been consolidated as a research area in the last ten years. At this period, the predominance of the case studies lends to the area an introductory phase of the theoretical processes. This present article foresees to advance in this perspective and to present methodological models that have been tested by different researchers in the proposition of a theory of journalism, which aims to endorse studies and researches in telejournalism in Brazil. To do so, it presents, in the first part, the methodological paths most used in recent years by study groups and reference research, and, in the second part, it explains two methodological proposals that contemplate the audience, the reception and the research processes undertaken.

\section{Keywords}

Telejournalism; research; methodology; audience analysis; reception analysis.

|MAGINAR' 


\section{A centralidade dos estudos em}

Telejornalismo

No campo dos estudos sobre a televisão, há um foco muito produtivo no desenvolvimento de pesquisas em torno da ficção televisiva e de formatos e gêneros privilegiadamente ficcionais. Porém, o jornalismo de televisão, ou o telejornalismo, recebia pouca atenção, uma situação que vem se invertendo nos últimos dez anos. Nesta nova perspectiva, os estudos em telejornalismo iniciaram por outras áreas como a sociologia, a antropologia, a filosofia e, até mesmo a psicologia, entre outros. Uma análise mais geral sobre os resultados da maioria destes trabalhos permite afirmar que eles partem de perspectivas ideais, ou seja, tentam analisar, criticar ou estudar os processos do telejornalismo focando no que ele deveria fazer e não no que ele realmente faz.

Assim, há um campo aberto para pesquisas em telejornalismo que mantenham o foco nos fazeres produtivos, nas suas especificidades e, principalmente, na análise sobre o que o telejornalismo vem produzindo e como ele vem se desenvolvendo ao longo dos anos. Esta perspectiva teórica e metodológica pode promover uma abertura fulcral nos estudos no campo do telejornalismo que permita fazer circular o conhecimento, alimentar a formação profissional, potencializar a qualidade das produções existentes no mercado, bem como promover uma oxigenação nos próprios estudos acadêmicos sobre o tema.

Diante do exposto, o presente artigo se propõe a apresentar alguns percursos teóricos e metodológicos em telejornalismo que vêm sendo utilizados por diferentes grupos de trabalho no Brasil de forma produtiva e com resultados extremamente pertinentes e contributivos. Nesta esteira estão os trabalhos realiza- dos pelo Grupo Análise em Telejornalismo (Universidade Federal da Bahia), pelo Grupo Interinstitucional de Pesquisa em Telejornalismo (Universidade Federal de Santa Catarina) e pelo Grupo de Pesquisa Televisão e Audiência (Pontifícia Universidade Católica do Rio Grande do Sul). Além destes, apresenta-se também aqui a proposta desenvolvida pelo Grupo de Pesquisa em Jornalismo On-Line (GJOL), da Universidade Federal da Bahia, porque sua metodologia oferece uma funcionalidade operacional aos estudos de televisão e do telejornalismo.

O texto inicia por uma breve discussão sobre a conceituação do campo e do próprio termo telejornalismo e depois desdobra as metodologias empregadas pelos grupos citados. Ressalta-se que neste aspecto, investe mais na apresentação de duas propostas metodológicas que permitem estudar o receptor de notícias em diferentes suportes: o televisual e os dos dispositivos móveis. A ênfase no aspecto da recepção reflete a preocupação das pesquisas empreendidas pelas autoras nos últimos dois anos.

\section{Sobre as telas do telejornalismo}

Há alguns anos o termo telejornalismo tem sido definido como o jornalismo produzido para e pela televisão. Com o avanço paulatino das novas tecnologias e do campo de atuação do jornalismo em diferentes telas, se faz necessário repensar se esta concepção ainda consegue definir o tipo específico de jornalismo audiovisual e suas infinitas possibilidades narrativas.

Assim, o artigo propõe desmembrar o próprio termo telejornalismo e compreender se há possibilidades semânticas de ampliá-lo para além do senso comum que o compreende de forma direta ligada à televisão. $\mathrm{Na}$ época de seu surgimento, se definiam as imagens pelo seu suporte, porque os suportes teriam características definidas, cujas fronteiras expressivas eram passíveis de delimitação. Se não, vejam. Fotojornalismo, o jornalismo que utilizava as imagens fotográficas para narrar sobre as histórias do mundo. Cinejornalismo, que se fundava nas imagens capturadas pela câmera cinematográfica, e telejornalismo, aquele que remetia às imagens capturadas pela câmera de vídeo analógico, da televisão.

O que se propõe repensar, a partir destes processos de hibridação constantes das produções contemporâneas e o surgimento de novos suportes, é que o termo "tele" talvez possa ser problematizado a partir da concepção de telas e não apenas especificamente a tela televisiva. Neste aspecto, pode-se compreender por "tela", partindo de glossários de termos técnicos, manuais de tecnologia digital ou mesmo pelos dicionários como um nome mais genérico para designar superfície (quadro, material refletivo) para a projeção (frontal ou traseira) de imagens.

Para pensar "tele", primeiro se recorre ao dicionário etimológico que o escreve com grafia tel(e) e o define como elemento composto do grego que está ligado à noção de longe, longe de ou ao longe; podendo remeter, também à noção de distância ou de modelo de transmissão de dados a distância. Este último, aliás, é a própria essência da definição de telecomunicação, segundo o glossário publicado pela Anatel (BR):

telecomunicação 1. (Dec 97057/88) comunicação realizada por processo eletromagnético. 2. (RR) qualquer transmissão, emissão ou recepção de símbolos, sinais, texto, imagens e sons ou inteligência de qualquer natureza através de fio, de rádio, de meios ópticos ou de qualquer outro sis- 
tema eletromagnético. telecomunicação analógica 1. (Dec $97057 / 88)$ telecomunicação de informação codificada com o uso de técnica analógica. telecomunicação digital 1. (Dec 97057/88) telecomunicação de informação codificada com o uso de técnica digital (Anatel, 2017).

Ou seja, se articularmos estas definições podemos afirmar que Tele + Jornalismo seria um jornalismo feito para ser distribuído para e/ou ao longe, ou ainda, transmitido para lugares distantes, muito mais do que um jornalismo para ser exibido apenas numa tela de visão (definição mais comum do aparelho televisão).

Assim, numa primeira acepção, este trabalho assume a perspectiva de que estudar telejornalismo é estudar um jornalismo para as telas, incluindo televisão computador, smartphone, celular, tablets ou os demais dispositivos e suportes que se utilizem de uma tela de visão ou de uma tela refletiva para exibir dados ${ }^{5}$. Definido o escopo da proposta propõe-se, a seguir, apresentar de forma breve as metodologias que vêm sendo empregadas no campo dos estudos em telejornalismo cujos resultados têm ajudado a fortalecer e ampliar as pesquisas específicas do campo.

\section{Alguns percursos metodológicos de} análise em telejornalismo

O grupo Análise em Telejornalismo da UFBA propõe uma articulação teórica entre os cultural studies e a teoria da linguagem para compreender o que definem como os modos de endereçamento. A saber:

Modo de endereçamento é aquilo que é característico das formas e práticas comunicativas especí- ficas de um programa, diz respeito ao modo como um programa específico tenta estabelecer uma forma particular de relação com sua audiência (cf. Morley \& Brunsdon, 1978). A análise do modo de endereçamento deve nos possibilitar entender quais são os formatos e as práticas de recepção solicitadas e construídas pelos telejornais (Mota Gomes, 2007, p. 4).

O conceito de modos de endereçamento, tal qual afirma Mota Gomes, surge nos estudos sobre a análise fílmica, ligada à screen theory, sendo aplicado à produção televisual na perspectiva de compreender a relação dos textos televisivos com seus receptores. $A$ proposta metodológica do grupo Análise em Telejornalismo considera aspectos históricos, sociais, ideológicos e culturais do telejornalismo, empregando operadores de análise que se constituem em: 1) mediador, 2) contexto comunicativo, 3) pacto sobre o papel do jornalismo, e 4) organização temática e sua relação com premissas e conceitos adotados. Tal proposta se funda em outros dois conceitos metodológicos operacionais, além dos modos de endereçamento: estrutura de sentimento, advinda de Raymond Williams; gênero televisivo, advindo dos estudos do grupo a partir de Raymond Williams, Martín Barbero e Stuart Hall ${ }^{6}$.

O grupo de Pesquisa em Jornalismo On-Line (GJOL) propõe um modelo híbrido de pesquisa, cuja metodologia opera no âmbito teórico e empírico e articula procedimentos qualitativos e quantitativos de forma complementar. A partir dos pressupostos apresentados por Marcos Palacios e Elias Machado, desenvolvidos desde 1995, o pesquisador atua em três macro-etapas:
1) Revisão preliminar da bibliografia, acompanhada da análise de organizações jornalísticas relacionadas ao objeto de estudo; 2) Delimitação do objeto com formulação das hipóteses de trabalho e estudos de caso com pesquisa de campo (participante ou não) nas organizações jornalísticas e 3) Elaboração de categorias de análise, processamento do material coletado e definição conceitual sobre as particularidades dos objetos pesquisados (Machado e Palacios, 2006, p. 47).

Nesta perspectiva, o GJOL assume o jornalismo como fenômeno e o compreende como processo, sendo possível aliar aos preceitos da investigação o mesmo percurso da produção tradicional em jornalismo, ou seja, apuração, produção, circulação e consumo de informações. A perspectiva do grupo é que esta metodologia possa contemplar a revisão bibliográfica sobre o objeto e também possa permitir a testagem do referencial conceitual em estudos de caso específicos.

No Grupo Interinstitucional de Pesquisa em Telejornalismo, da Universidade Federal de Santa Catarina, a semiótica discursiva tem guiado algumas das análises que pretendem compreender o telejornalismo em suas especificidades. A semiótica discursiva se propõe a ser uma teoria geral da significação bem como uma metodologia operatória para a descrição dos discursos e das práticas sociais.

Estudar, portanto, o telejornalismo compreendido pela acepção semiótica é olhar para o seu modo de produção de sentido, ou a maneira que este se constrói para provocar significações e interpretações. Considerando-se um campo de conhecimento específico, a semiótica quer estudar os processos de produção de significação e sentidos, organizando metodologias 
que possibilitem "articular produção e reconhecimento dos sentidos, considerando os diferentes sistemas culturais e sociais em que essas instâncias estão inseridas" (Emerim, 2014, p. 108). O maior desenvolvimento operacional da Semiótica Discursiva ocorre com Algirdas Greimas e a Escola de Paris, quando postula o discurso como foco de seus estudos sobre qualquer tipo de texto. Greimas acredita que uma estrutura narrativa pode se manifestar em qualquer tipo de texto e estabelece três níveis de análise para explicar a geração de discursos de qualquer sistema semiótico: 1) estruturas semio-narrativas, 2) estruturas discursivas e, por fim, 3) estruturas textuais.

Assim, o método, de inspiração pós-estrutural, é uma análise empírica, de caráter teórico-prático, que centra a ênfase no exame do nível discursivo, considerando a televisão e seus produtos a partir de seu contexto e, por isso, algumas premissas metodológicas devem ser previstas no interior da própria proposta analítica (Emerim, 2014, p. 113).

Se cada produção midiática telejornalística é um texto, compreendendo que ele tem marcas discursivas expressas neste texto e que permitem o seu reconhecimento, a centralidade da análise no nível discursivo permite descrever e entender o processo de significação, bem como para a que público esta produção se destina. Assim, o método prevê um percurso que descreva, analise e interprete iniciando pela linguagem, passando pelas técnicas e as especificidades de sua natureza e, por fim, contemple a recepção. Sem esquecer-se do contexto que parte da compreensão do papel social e da função que o telejornalismo exerce na sociedade contemporânea.
A seguir apresenta-se uma proposta metodológica intitulada Análise do telespectador discursivo, que iniciou no GIPTele com base e nos princípios da semiótica discursiva e que está em fase de potencialização e ampliação.

\section{Análise do telespectador discursivo}

Procurando compreender os fatores que podem influenciar sucessos e fracassos de audiência no contexto do telejornalismo, esta proposta mantém o foco no relacionamento estabelecido entre o programa e seus telespectadores por meio de contratos comunicativos. Portanto, esta proposta de análise dos telejornais tem como pressuposto que o programa televisivo propõe ao telespectador um relacionamento, estabelecendo regras para sua leitura. Tais regras se manifestam no texto televisivo na forma de marcas discursivas, como vestígios das operações realizadas pela instância de enunciação que podem ser observadas e analisadas.

Assim, chega-se ao que propomos chamar de telespectador discursivo, um conceito operacional que representa a configuração das estratégias comunicativas operadas no programa que sustentam o contrato estabelecido entre ele e seu público. Assume-se, em concordância com Fausto Neto, que a instância de recepção "é construída já no interior do próprio processo discursivo por meio de múltiplas operações articuladas pelos processos da própria linguagem" (1995, p. 194). Para o autor, o discurso jornalístico "arruma" o receptor em uma posição conveniente para a leitura do texto e, assim, os telespectadores são "capturados".

O telespectador discursivo não representa uma construção sociológica, ao contrário, ele é da ordem da virtualidade, uma vez que é observável apenas no interior do texto televisivo. Em outras palavras, esta abor- dagem não indica um perfil sócio-demográfico dos potenciais telespectadores de um programa, assim como não aponta qual perfil de público é imaginado pelos produtores do telejornal. $\mathrm{O}$ conceito aplicado à análise relaciona-se com o telespectador que é configurado no texto, independente da intenção dos produtores.

Esta abordagem metodológica encontra subsídios teóricos nos estudos literários - que muito antes do desenvolvimento dos estudos das mídias e seus receptores já discutiam a construção do destinatário no discurso $^{7}$ - e também em pesquisas realizadas já no contexto televisivo:

Portanto, a proposta metodológica do telespectador discursivo se relaciona com os modos de dizer, ou seja, com as estratégias discursivas operadas tanto no âmbito do conteúdo quanto no aspecto expressivo. No contexto da produção televisiva, as estratégias discursivas compreendem as escolhas relacionadas à estruturação do conteúdo televisivo, responsáveis pela organização do "modo de dizer" dos programas (Duarte, 2000). O percurso de análise proposto está esquematizado em três etapas, como demonstra a Figura 1.

A primeira etapa procura avaliar a relação dos programas com o contexto comunicacional, com a emissora e com a grade de programação onde o programa está inserido. Estas categorias são fundamentais para a compreensão dos modos de funcionamento do programa, uma vez que o contexto mercadológico tem implicações diretas no resultado dos programas (Emerim, 2010). Como exemplo, podemos considerar dois telejornais locais concorrentes, exibidos na mesma faixa de horário. Um deles, porém, é precedido na grade de programação por um programa de variedades com grande audiência nacional enquanto outro é exibido logo após um desenho animado em um canal que, historicamen- 

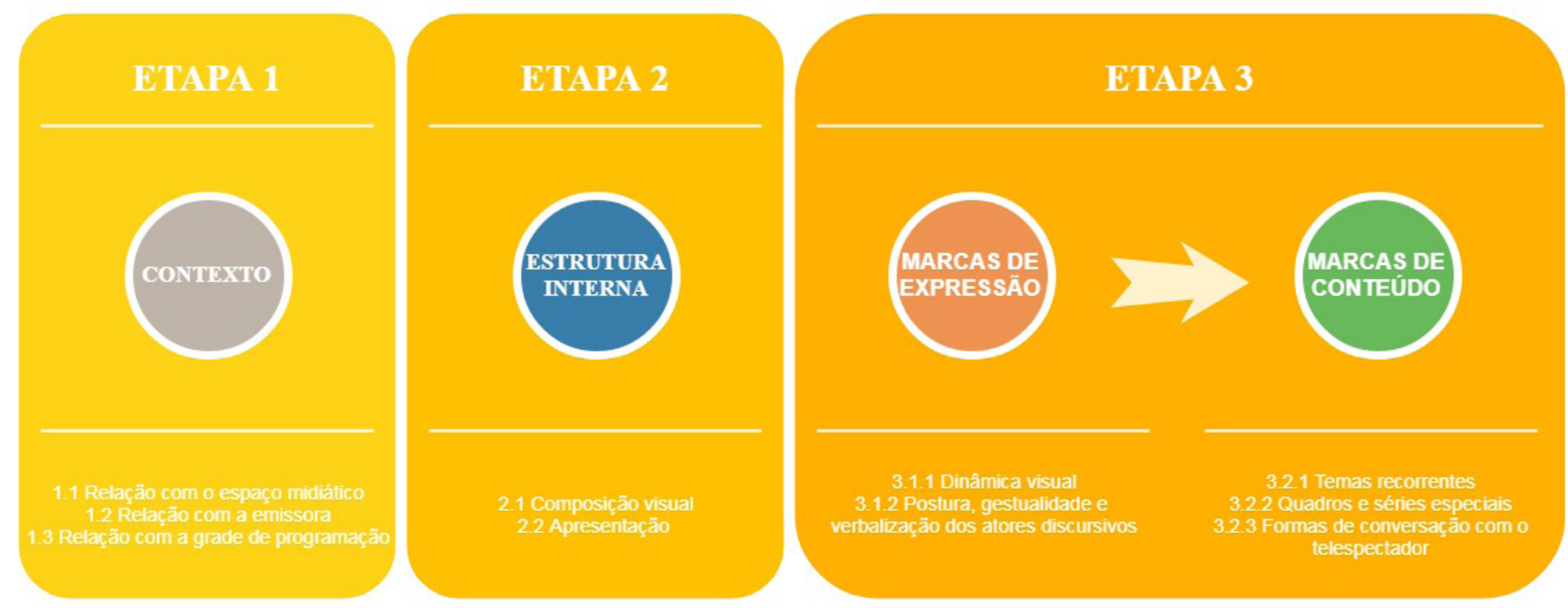

Figura 1: Esquema das etapas de análise.

Fonte: Cavenaghi, 2013.

te, apresenta baixos índices de audiência. Mesmo que os dois telejornais tenham operações enunciativas muito parecidas, o contexto comunicacional em que estão inseridos terá impactos diferentes para o resultado de cada um deles.

Na segunda etapa da análise são observados os aspectos expressivos relacionados com a estrutura interna do telejornal e que se repetem em todas as suas edições. Eles são divididos em duas categorias: (1) composição visual, incluindo elementos como vinheta e cenário, considerando o tamanho do espaço, as cores pre- dominantes e os elementos de cena; e (2) apresentação, onde são observados o perfil, a trajetória e a formação profissional de cada um dos atores discursivos.

A terceira etapa divide-se entre o plano da expressão e o do conteúdo'. No plano da expressão, observa-se (1) a dinâmica visual do programa, com foco no uso dos elementos que compõem o cenário, além dos enquadramentos e movimentos de câmera mais frequentes; (2) aspectos da postura, da gestualidade e da verbalização dos apresentadores e de outros atores discursivos (apresentadores, colunistas e comentaristas), destacando a maneira como eles se movimentam em cena, o tom de voz, a velocidade da fala e outras características marcantes que possam demonstrar como tentam se relacionar com o telespectador, chamar sua atenção ou estabelecer com ele uma afinidade. No plano do conteúdo, observa-se (1) os temas recorrentes (2) os quadros fixos e as séries especiais exibidas no programa. A análise destas duas categorias parte de um levantamento quantitativo das matérias exibidas para identificar possíveis "tendências temáticas". Por fim, a categoria (3), formas de conversação direta com o teles- 
pectador, observa o texto falado por apresentadores e repórteres, procurando em especial marcas do relacionamento com o telespectador.

$\mathrm{Na}$ experiência de aplicação desta metodologia de análise, foi possível destacar os modos de dizer dos telejornais e, assim, observar aspectos que diferenciam cada programa - mesmo que sejam muito parecidos em seus formatos. Cada programa opera diferentes estratégias para construir seus discursos e, como consequência, construir seus contratos comunicativos com os telespectadores. Quando observamos estas estratégias - através das categorias de análise aqui apresentadas - podemos inferir sobre o relacionamento proposto ao telespectador e, assim, sobre o perfil de telespectador discursivo configurado no texto.

\section{Telejornalismo e os indicativos para uma narrativa transmedia}

A televisão vive um momento de incertezas, tanto pela mudança da plataforma analógica para digital, quanto pela sua real vocação frente aos produtos oferecidos por outras mídias, principalmente as digitais. $O$ jornalismo também passa por um questionamento importante quanto ao papel que desempenha junto à sociedade que, cada vez mais, é produtora dos seus próprios conteúdos.

Todas as mudanças atingem diretamente as rotinas de produção, a cultura das redações, os conteúdos informativos e a distribuição deles, as estratégias narrativas, assim como as relações com a audiência. Enquanto algumas tecnologias disponíveis estão em implantação e outras ainda em desenvolvimento, é preciso projetar novos modos de atuação, tantos dos profissionais como dos telespectadores.
Não é porque existe a tecnologia que o público vai adotá-la. A adoção e o sucesso de uma tecnologia dependem de sua adequação à demanda e às expectativas do público em determinado momento. No caso da televisão, temos de pensar em quais tipos de interatividade vão agradar o público (Cannito, 2010, p. 155).

Para o desenvolvimento do telejornalismo dentro deste contexto, além das outras telas como computadores, tablets, celulares e consoles de videojogos é preciso pensar em novos paradigmas, como afirmou Scolari (2004): a articulação da TV com outras mídias interativas; o empoderamento do telespectador; a interação entre emissor/receptor; a interação entre receptor/receptor; a possibilidade de acesso a qualquer hora e lugar; o uso da interatividade digital para customizar programação e programas; o fim das fronteiras rígidas entre conteúdo e publicidade; o fim da linguagem audiovisual padrão da TV; a adoção da linguagem multimídia, transversal, interativa com a colaboração do usuário.

Ainda, segundo o autor, este é o tempo da hipertv uma televisão instalada em rede, nos termos definidos por Castells (1999), conectada com outras plataformas, libertando-se aos poucos da programação em fluxo e lançando mão de narrativas transmidiáticas.

De acordo com Jenkins (2009), a narrativa transmedia entrou em debate público pela primeira vez em 1999, com o lançamento do filme independente $A$ Bruxa de Blair. Desde então, a indústria do entretenimento tem aplicado estas estratégias, que vão além de transpor um conteúdo de um meio para outro. Trata-se da expansão do produto que vai ser alterado e complementado por outros conteúdos, até mesmo pelos usuários, em dife- rentes meios e suportes.

Os estudos de recepção já eram suficientemente complexos nas chamadas mídias tradicionais. A partir da perspectiva de que a relação dos meios de comunicação publicos não é direta, as chamadas teorias hipodérmica e funcionalistas foram substituidas pelas teorias críticas, culturológicas e comunicativas (Wolf, 1994).

Agora com as novas tecnologias, há o empoderamento do receptor. A expectativa é mapear as mudanças no campo da recepção das notícias veiculadas nos telejornais, quando acontece em outras locais (fora de casa), em outras situações de atenção (em atitude de espera ou deslocamento), com outros dispositivos e telas.

Nas mídias tradicionais os receptores eram considerados, muitas vezes, apenas como consumidores passivos, previsíveis, estáveis e até leais a algumas empresas. Agora, devem ser pensados como usuários ativos, migratórios ou nômades, conectados socialmente e, por isso mesmo, receptores barulhentos (Jenkins, 2009).

Ainda no campo da recepção dois fenômenos começam a ser estudados na perspectiva também do telejornalismo. A segunda tela, que é o uso de novos dispositivos como smartphones, tablets, notebooks, entre outros, de forma simultânea à programação da TV. Essa navegação paralela permite o consumo de conteúdos editoriais complementares (saber mais sobre a reportagem, os repórteres, os apresentadores, as fontes, o contexto, outras notícias afins)

A SocialTV compartilha informações, impressões, opiniões com outros telespectadores através das redes social. A experiência torna-se mais complexa e rica, as pessoas fazem questão de assistir também ao vivo para acompanhar o que os outros 
estão falando sobre determinada notícia. O que se diz na rede repercute e, muitas vezes, pode interferir imediatamente no conteúdo veiculado.

Mais do que adotar uma única metodologia, o que o Grupo de Pesquisa Televisão e Audiência tem se proposto é a pensar o futuro do telejornalismo sob o prisma destes novos fenômenos, destes novos conceitos, destes novos atores, desta nova realidade.

\section{Considerações Finais}

As metodologias brevemente apresentadas neste artigo podem ser aplicadas aos estudos em telejornalismo e aos dos produtos televisuais, de modo geral. O número de publicações em livros, artigos em revistas certificadas e da produção científica, em diferentes âmbitos (graduação e pós-graduação), credenciam a eficácia destas metodologias na análise das questões cruciais para o telejornalismo.

A proposta do artigo foi a de apresentá-las e poder dividir com o campo, os percursos e os pressupostos das análises, a fim de discutir suas possibilidades e restrições, bem como ampliar suas proposições no âmbito do telejornalismo, visando, cada vez mais, o fortalecimento desta área em específico, como uma área fundamental para o jornalismo contemporâneo.

Ressalta-se, também, a pertinência da discussão sobre o termo ou o conceito de telejornalismo, trazida pelo artigo de forma breve, mas que merece uma imersão mais aprofundada por parte dos estudiosos da área. A proposta inaugural aqui trazida compreende telejornalismo como um campo específico do jornalismo que se dedica ao estudo das produções exibidas em telas, sendo elas televisão, tablet, écran do computador ou de celular, com base móvel ou fixa. Embora se tenha já um campo aberto para o telejornalismo em dispositivos móveis e novas telas, há ainda, um enorme espaço aberto para pesquisas que possam, de fato, compreender a televisão e o jornalismo feito para a televisão. Tanto do ponto de vista histórico quanto de formatos e linguagens. Que dirá dos implementos tecnológicos que foram en-formando e con-formando a produção em telejornalismo na televisão aberta e fechada.

Portanto, não se trata apenas de marcar um lugar de fala específico e pertinente ao telejornalismo nos estudos contemporâneos do jornalismo, trata-se, acima de tudo, de uma escolha epistemológica de fundo, que não só caracteriza os estudos empreendidos pelos grupos aqui representados como também aponta uma reflexão geral em torno da natureza desta especificidade, considerando as relações que estabelece com a sociedade e com os sujeitos. É uma escolha epistemológica, porque aponta para o desenvolvimento de uma teoria que versa sobre um conhecimento específico que, assim como a teoria do jornalismo, articula-se em modos de ser e modos de fazer que determinam sua característica de natureza híbrida.

A consistência desta premissa apresenta-se pelas metodologias aqui descritas e pelos resultados que as pesquisas da área têm permitido trazer para compor este campo teórico específico. Não obstante, reitera-se o percurso, em pleno desenvolvimento, sobre o estudo de postulados e métodos, de teorias e práticas dos diferentes ramos dentro do telejornalismo que permitam efetivar as conclusões pertinentes a esta que poderemos intitular, daqui a algum tempo, de teoria do telejornalismo, embora, para os autores deste artigo, já é um campo existen- te em plena consolidação.

Por fim, mais do que postular conclusões, o artigo se propõe a abrir o espaço de discussão e quer, de fato, convidar os pesquisadores de e sobre o Telejornalismo a se debruçarem sobre esta temática, auxiliando no desenvolvimento dos pressupostos aqui trazidos, de modo democrático e coletivo, como forma de ampliar o debate e fortalecer o constructo teórico que se almeja.

\section{Referências}

ANATEL. Glossário de Termos da Anatel: Telecomunicação. Disponível em: <http://www.anatel.gov. $\mathrm{br} /$ legislacao/o?view $=$ faq $\&$ catid $=20$ \& search $=$ telecomunica\%C3\%A7\%C3\%A30\%201\&faqid=1174>. Acesso em: 5 jul. 2017.

CANNITO, Newton. A Televisão Digital: Interatividade, convergência e novos modelos de negócios. São Paulo: Summus, 2010.

CASTELLS, Manuel. A sociedade em rede. São PauIo: Paz e Terra, 1999.

CAVENAGHI, Beatriz. Telejornalismo local: estratégias discursivas e a configuração do telespectador. Florianópolis: Universidade Federal de Santa Catarina, 2013. 153p. Dissertação de Mestrado em Jornalismo do Programa de Pós-Graduação em Jornalismo.

DUARTE, Elizabeth Bastos. Reflexões sobre o texto televisivo. In: CONGRESSO BRASILEIRO DE CIÊNCIAS DA COMUNICAÇÃO. 23, Anais... Manaus. 2000.

ECO, Umberto. Lector in fábula. São Paulo: Pers- 
pectiva, 1986.

EMERIM, Cárlida. Análise de telejornalismo: uma proposta metodológica. In: ENCONTRO NACIONAL DE PESQUISADORES EM JORNALISMO. 8, Anais... São Luiz. 2010

Telejornalismo e Semiótica Discursiva. In: VIZEU, Alfredo; MELLO, Edna; PORCELLO, Flávio; COUTINHO, Iluska (orgs.). Telejornalismo em questão. Florianópolis: Insular, 2014.

FAUSTO NETO, Antônio. A deflagração do sentido: estratégias de produção e de captura da recepção. In: SOUZA, Mauro Wilton. Sujeito, o lado oculto de receptor. São Paulo: Brasiliense, 1995.

GREIMAS, Algirdas Julien. Dicionário de Semiótica. São Paulo: Cultrix, s/d.

; LANDOWSKI, E. Análise do Discurso em Ciências Sociais. São Paulo: Global, 1986.

JENKINS, Henry. Cultura da convergência. São Paulo: Aleph, 2009.

MACHADO, Elias; PALACIOS, marcos. Um modelo híbrido de pesquisa: a metodologia aplicada pelo GJOL. In: LAGO (org.), Claudia; BENETTI, Márcia. Metodologia de Pesquisa em Jornalismo. São Paulo: Paulus, 2006.

MOTA GOMES, Itânia Maria. Questões de Métodona análise do telejornalismo: premissas, conceitos, operadores de análise. Revista E-Compós: 2007 (abril).
SCOLARI, Carlos. Hacer Clic. Hacia una sociosemiótica de las interacciones digitales. Barcelona: Gedisa, 2004.

VERON, Eliseo. Quando ler é fazer: a enunciação no discurso da imprensa escrita. In: VERÓN, Eliseo. Fragmentos de um tecido. São Leopoldo: Editora Unisinos, 2004.

VIZEU, Alfredo. Telejornalismo: das rotinas produtivas à audiência presumida. In: VIZEU, Alfredo; MOTA, Célia Ladeira; PORCELLO, Flávio Antônio Camargo. Telejornalismo: a nova praça pública. Florianópolis, SC: Insular, 2006.

. Decidindo o que é notícia: os bastidores do telejornalismo [2000]. Porto Alegre: EDIPUCRS, 2005.

WOLF, Mauro. Teorias da Comunicação. Lisboa: Presença, 1994.

\section{Notas}

1 Uma versão deste artigo foi apresentada no 130 Encontro Nacional de Pesquisadores em Jornalismo, realizado em Campo Grande (UFMS), em novembro de 2015.

2 Jornalista, Mestre em Semiótica, Doutora em Processos Midiáticos, professora e pesquisadora na Graduação e Pós-Graduação em Jornalismo da Universidade Federal de Santa Catarina (POSJOR/UFSC - Campus Trindade Bloco A CCE Departamento de Jornalismo, Bairro Trindade, Florianópolis/SC, Brasil, CEP: 88000000), Líder do Grupo Interinstitucional de Pesquisa em Telejornalismo (GIPTele). E-mail: carlidaemerim@ gmail.com.

3 Jornalista, Doutora em Comunicação, professora do Curso de Jornalismo e pesquisadora no Programa de Pós Graduação em Comunicação Social da PUCRS (PPGCOM/PUCRS - Av. Ipiranga, 6681, Bairro Partenon, Porto Alegre/RS, Brasil, CEP: 90619-900), Coordenadora do Grupo de Pesquisa: Televisão e Audiência. E-mail: cristiane.finger@pucrs.br.

4 Jornalista, Mestre em Jornalismo, Doutoranda em Engenharia e Gestão do Conhecimento (UFSC), pesquisadora do Grupo Interinstitucional de Pesquisa em Telejornalismo (GIPTele), professora do IELUSC (Rua Princesa Isabel, 438, Centro, Joinville - Santa Catarina. Cep. 89301-270). E-mail: cavenaghi.bea@gmail.com.

5 Esta discussão é melhor realizada por Emerim (2014) e em capítulo de livro do Grupo Interinstitucional de Pesquisa em Telejornalismo que está no prelo.

6 Os principais textos que permitem conhecer com mais vagar esta metodologia estão citados especificamente nas referências bibliográficas.

7 Ver, por exemplo, Eco (1986).

8 Ver, por exemplo, o trabalho de Alfredo Vizeu (2005; 2006).

9 Considera-se que expressão e conteúdo são complementares e indissociáveis, mas, aqui, esta divisão ajuda a operacionalizar a análise. 